\title{
ДИПЛОМАТИЧЕСКИЕ ОТНОШЕНИЯ БНР И ПРАВИТЕЛЬСТВА ПАВЛА СКОРОПАДСКОГО (1918)
}

\author{
АЛЕКСАНДР КУКСА (Минск, Республика Беларусь)*
}

В свете событий Февральской революции и последовавшей борьбы за автономный статус Украины в составе России, Минск, как центр Западного фронта, на котором находилось около 100 тысяч солдат-украинцев, приобретал все большее значение для Украинской Центральной рады (УЦР). Как позже указывал на встрече с корреспондентами в КаменцеПодольском заместитель посла Белорусской Народной Республики в Украине А. Головинский, именно в Минской губернии С. В. Петлюра начал создавать первые национальные военные формирования.

В помещении медицинского бюро Земского союза 28 марта 1917 г. состоялось общее собрание украинцев, в котором приняли участие около 300 солдат, офицеров, работников фронтовых общественных организаций и жителей Минска. Председатель собрания С. В. Петлюра призвал собрание к организации украинских сил на фронте, ибо «только организованный народ сможет использовать ту свободу, которую теперь получил, и закрепить свои политические и национальные права, которые наиболее полно смогут выявиться при демократически-республиканском и федеративном устройстве России, с автономной Украиной» [1, с. 2]. Для проведения в жизнь своих постановлений собрание признало необходимым создавать украинские кружки, войти в сношения с Украинской Центральной Радой и с местными организациями - Советами рабочих и солдатских депутатов, Солдатско-офицерской комиссией, Белорусским комитетом и другими. Было принято решение провести в Минске и на фронте несколько украинских митингов, организовать с целью сбора средств на фронтовые организации «День вільної України», опубликовать воззвание с призывом к организации. В Совет Минской громады, выделенный на собрании, вошли 20 чел.

В июне 1917 г. в Минске был создан Временный Украинский комитет Западного фронта. Под его руководством среди украинских солдат распространялись брошюры, газеты и листовки, в которых звучал призыв создать национальные воинские части. В помещении фронтового комитета 10 июля 1917 г. состоялось общее собрание около 600 членов украинской громады под председательством К. Новохацкого. После прочтения 2-го 
универсала УЦР, постановлений Временного правительства и произнесения речей, поясняющих эти акты, была принята резолюция, в которой собрание постановило: «поддерживать всеми способами, созданные революционной демократией и уполномоченные ею органы революционной власти, как на Украине, так и в России вообще, в их борьбе за укрепление завоеваний революции» [2, с. 2].

На 1-м съезде украинских организаций начала работу Украинская рада Западного фронта (УРЗФ), которой поручалось вступить в контакт с Белорусским национальным комитетом (БНК). Присутствовавший на съезде представитель Белорусской социалистической громады (БСГ) Л. И. Заяц заявил о необходимости сближения белорусских и украинских организаций и сообщил о возможности оказания поддержки, в виде предоставления Украинской громаде помещения в Белорусской хатке.

Украинские организации повели активную деятельность на территории Белоруссии. УРЗФ организовала свое помещение в Минске, расположив там библиотеку, установила мебель, приобрела канцелярские принадлежности. После разгрома этого помещения большевиками в декабре 1917 г., УРЗФ оценила потерю имущества в значительную для того времени сумму - 22000 руб.

Белорусские и украинские политические организации включились в общую работу по подготовке населения $к$ демократическим и федеративным преобразованиям. Украинские партии эсеров (УПСР), федералистов (УПСФ), демократов (УПСД) и БСГ провели ряд митингов, общественных сходов и праздников, выступили одним блоком на выборах в органы местного самоуправления. Но 30 июля 1917 г. блок национальных социалистических партий потерпел ощутимое поражение на выборах в Минскую городскую думу, проведя только 4-х депутатов. В Минскую думу попали лишь два представителя от белорусских партий и то только потому, что одно место им уступили представители украинских партий.

В декабре 1917 г. между РСФСР и Украинской Народной Республикой (УНР) началась война. Текст ответа УНР о неправомерности действий СНК РСФСР против Украины был распространен Украинской фронтовой радой среди солдат Западного фронта с призывом поддержать УНР. Руководители Областного исполнительного комитета (Облискомзапа) Западного фронта, среди членов которого белорусов не было, восприняли ноту Генерального секретариата, информацию в белорусской печати и 
обращение М. М. Лебединца* как факт создания реальной угрозы для советской власти. В связи с этим А. Мясников в начале декабря 1917 г. запретил выделение украинских национальных частей, а в случае движения их на Юг приказал задерживать, устроив заслоны на станциях Минск, Лунинец и Сарны.

Из письма председателя Украинской фронтовой рады М. М. Лебединца к правительству УНР следует, что он и весь состав УРЗФ 7 декабря 1917 г. были арестованы Облискомзапом. Под арестом находились до 17 февраля 1918 г. После ареста членов рады в Минске была создана следственная комиссия при СНК Западной области и фронта в составе: К. Г. Кнорин, С. И. Берсон и П. П. Осипов. Всего арестовали 9 человек, из которых членами рады УРЗФ являлись: А. Я. Ермак, М. И. Спасский, П. Д. Косяк, М. М. Лебединец и А. Г. Золотницкий. Аресты на этом не прекратились. В Минск продолжали прибывать делегаты на Всебелорусский съезд.

Под предлогом подготовки восстания Центральной белорусской войсковой радой совместно с польским корпусом Довбор-Мусницкого (появилась информация о выделении УНР белорусам 11 тыс. руб. на создание армии), прибывавшие делегаты от Юго-Западного фронта арестовывались. В январе 1918 г. ЦБВР и органы местного самоуправления были распущены Облискомзапом.

В феврале 1918 г. возобновляются военные действия на Восточном фронте. Немецкие войска оккупировали Минск и большую часть Белоруссии. Учитывая предшествующие события и отсутствие помощи и защиты со стороны белорусов, члены УРЗФ введя в свой состав председателя Украинской минской громады К. Новохацкого и ее члена

\footnotetext{
* Лебединец Михаил Моисеевич, 28 лет, прапорщик, председатель фронтовой войсковой украинской рады, член УПСР. На вопрос о том, признает ли он власть Центрального СНК и местную советскую власть ответил, что он эту власть на месте признает, а что же касается Украины, то там он признает власть поставленную украинским народом - Центральную Раду. На вопрос о его действиях в случае начала открытого военного конфликта между УЦР и правительством СНК, Михаил Моисеевич заявил, что украинские части должны выполнять приказы УЦР. На вопрос о том, знает ли он о вызове в Минск украинских войск - ответил отрицательно. На вопрос «было ли выпущено воззвание к украинскому народу?» ответил, что на съезде украинских социалистов в Минске 6 декабря был выработан и разослан по телеграфу ответ на ультиматум правительства СНК правительству Украинской республики, к которому присоединилась и фронтовая украинская рада.
} 
В. Ситника, 21 февраля 1918 г. организовали «Мінський Комітет Охорони інтересів і прав підданих УНР». В состав комитета входили: М. Лебединец (председатель), К. Новохацкий (заместитель), М. Спасский (секретарь), А. Стасюк (казначей) и В. Ситник (член).

23 февраля 1918 г. Комитет провел общее собрание украинцев городской колонии, на котором организовали добровольный сбор денег и возобновили деятельность Минской Громады. Эти организации работали в тесном контакте: Громада принимала украинцев в свои члены, собирая за это членские взносы, а Комитет организовал стол по выдаче справок о подданстве УНР, тем кто «пред'явив у цей стіл картку від Міської Української Громади й давав свою власноручно підписану заяву в тому, що він визнає на Україні лише владу Центральної Ради та ії виконавчого органу - Ради Народних Міністрів» [4, л. 144]. Благодаря сотрудничеству немецких военных властей за месяц удалось отправить 2500 человек на Украину. О том, что немецкое командование было заинтересовано в переброске на территорию Украины именно военнообязанных, свидетельствует тот факт, что с первыми двумя эшелонами отправились только 500 гражданских лиц, а в дальнейшем Комитету запретили вообще включать их в списки. В письме к правительству УНР М. М. Лебединец сообщал не только о деятельности этих организаций но и давал характеристику белорусскому движению, указывая на слабость БНР и говоря о Минском комитете как о консульстве: «як видно з детального огляду праць Комітету Охорони та його завдань він в певній мірі виконував майже всі функції Консульства й усіма за консульство й лічився, не дивлячись на те, що не носив офіційно сієї назви» [4, л. 145].

Выехавшая из Минска в марте 1918 г. делегация БНР, в апреле провела ряд встреч с лидерами УЦР непосредственно в Киеве. По итогам этих встреч украинский премьер-министр В. Голубович 10 апреля выступил с докладом на заседании Рады народных министров. В докладе он информировал о провозглашении независимости Белоруссии, необходимости установления прочной связи с Минском и необходимости выделения займа в 500 тыс. руб. В ходе дискуссии по вопросу признания независимости БНР, С. Шелухин заявил, что это зависит от Украинской Центральной рады. М. Ткаченко предложил послать в Белоруссию специальных делегатов для ознакомления с ситуацией на месте, а Сидоренко заявил, что Министерство иностранных дел должно сначала выяснить отношение к этому вопросу заинтересованных государств. В итоге вопрос был снят с обсуждения, но Министерству иностранных дел поручили ответить, что «Рада народних міністрів принципово нічого не 
має проти признання Білоруської Народної Республіки незалежною і буде вживати заходів до переведення цієї справи в життя законним шляхом» [5, с. 262]. В то же время острая необходимость в топливе подталкивала Раду народных министров к установлению контактов с белорусской делегацией. На предложение белорусов о продаже дров, 15 апреля 1918 г. постановили выдать авансом 300 тыс. руб. в счет их стоимости. Впрочем, временно исполняющий обязанности Государственного контролера Симонов резонно заметил, что поскольку БНР не признается как государство, то и торговую операцию не с кем тогда официально оформить.

Некоторые успехи киевской миссии БНР и сложность продовольственного вопроса в Минске заставляли украинский Минский комитет более активно искать пути налаживания контактов с УНР. За апрель 1918 г. в Киев были направлены три человека с отчетами о деятельности украинского комитета в Минске. Но связь так и не удавалось наладить, так как посланцы не возвращались. Наиболее удачной оказалась поездка заместителя председателя Минской украинской громады А. М. Квасницкого. МИД Украины препроводило посланца к И. И. Красковскому, с которым и были обсуждены вопросы поставки вагонов для вывоза украинских беженцев на родину. По всей видимости, эта встреча и основные направления деятельности Комитета предшествовали открытию в Минске дипломатического представительства Украины.

В мае 1918 г. председатель Минской украинской громады К. Новохацкий в письме* МИД Украинской Державы указывал на то, что в связи с отсутствием возможности связаться по телеграфу, участники громады отправляют в Киев заместителя председателя Квасницкого и Ветринского. Срочность вопроса связана с тем, что в Минске тогда собралось около 3000 украинцев. В то же время, из России на Минск и Оршу предполагалось отправление большой группы украинцев (только из Козловского уезда Тамбовской губернии направлялось 20000 бывших жителей Холмской губернии). В свою очередь, немецкие власти заявили, что вагонов нет и не будет. Сложным было положение тех, кто уже прибыл в Минск: «військових, німці хоч і мало, але годують, а цивільним допомагати одмовили. На мої прохання відповідають, що без санкції українського уряду нічим допомогти не можуть» [6, л. 2-2 об].

\footnotetext{
* Письмо дошло в Киев 3 июня. После обработки оно было переадресовано Красковскому, о чем свидетельствует резолюция на письме, поставленная карандашом от руки.
} 
По сведениям А. М. Квасницкого, в лучшем положении находились несколько сот украинцев, которым была предоставлена небольшая продовольственная помощь. Сообщая о тяжелом материальном положении украинцев, А. М. Квасницкий указывал на то, что 150 обедов выдавалось бесплатно Украинской раде ежедневно органами местного самоуправления.

3 мая 1918 г. новое украинское правительство гетмана Павла Скоропадского принимает решение основать украинское консульское агентство первого разряда в Минске (во главе с А. М. Квасницким). Деятельность агентства началась 19 мая и должна была проходить в тесном контакте с правительством БНР. Об этом свидетельствует сообщение Квасницкого, что большие надежды на консульство возлагали белорусские общественные организации. Перед отъездом из Киева А. М. Квасницкий беседовал с белорусскими представителями, которые заявляли, что надеются на него «как прожившего 17 лет в разных местностях Белоруссии». Представители биржи и общества землевладельцев в Минске также «обещали придти на помощь» в налаживании экономических контактов с Украиной. В то же время, министр иностранных дел Украины указывал на то, что консульские представительства нужны были для охраны торговых интересов и для «возвращения украинских граждан, главным образом, из мест бывшей Российской империи» [7, л. 9].

Сведения о событиях на Украине, связанных с государственным переворотом, в результате которого к власти пришел гетман Павел Скоропадский, поступили в Минск только 4 мая 1918 г. Украинская колония в Минске была застигнута новой киевской властью совершенно не подготовленной. В помещении Украинской Рады в Минске 5 мая состоялось совещание представителей правления Украинской Рады, в котором по особому приглашению принимал участие и председатель Народного секретариата БНР. Совещание это «не вынося конкретных решений, подготовило почву для будущих совещаний, имеющих состояться официально» [8, л. 26 об]. После возвращения в Минск 3 июня А. М. Квасницкий посетил председателя Народного секретариата И. Я. Воронко, изложив цель своего назначения и свою роль в столице Белоруссии. Беседа председателя Народного секретариата с украинским консулом длилась около часа. На приеме присутствовал управляющий делами народного секретариата Л. И. Заяц. В это же время появляется сообщение о назревшей необходимости открытия в Москве БелорусскоУкраинской торговой палаты.

В связи с назначением в Минске украинским консулом 
А. М. Квасницкого киевская миссия БНР обратилась 11 мая к правительству Украины с предложением назначить белорусского консула в Киеве. Кандидатом предлагали доктора П. В. Тремповича, который стал 29 мая консулом БНР в Киеве (с 16 июня 1918 г. генеральным консулом являлся Г. Ф. Базаревич). До этого обязанности консульства исполняла Белорусская торговая палата. В связи с этими событиями А. И. Цвикевич заявил, что в факте вступления политических структур Украины в переговоры с представителями Рады БНР последние усмотрели скрытый акт признания белорусской независимости. А. И. Цвикевич призывал гетмана «продолжить переговоры и поддержать стремление БНР получить признание от Советской России» [10, л. 4]. 21 мая 1918 г. Народный секретариат БНР определился со своей позицией относительно гетманского правительства. Главной внешнеполитической задачей провозглашалось установление добрососедских отношений с Украиной. Народный секретариат БНР призывал установить правильную пограничную линию на основе этнического принципа, а также с учетом исторических, экономических и географических факторов. На этом фоне происходит политическая активизация украинских белорусов, особенно проживавших в Одессе и вокруг неё.

В отчете временного консула Украинского государства в Минске А. М. Квасницкого перед Министерством иностранных дел от 30 мая 1918 г. указывалось, что в Минск ежедневно прибывало 50-100 украинцев, которых война в большом количестве забросила в пределы Белоруссии, Польши и Литвы. Большинство, узнав об украинском консульстве, пробирались в Минск для того, чтобы с его помощью получить пропуск от немецкой власти для проезда в Украину. Всего в Минске собралось около 4000 украинцев с семьями. Вместе с генералом Московенко и полковником Половинцем, 23 мая 1918 г. Квасницкий посетил представителей немецкой власти, которые отнеслись к ним с большим уважением: «довідавшись про те, що я командирований новим урядом, німецька влада запевнила мене, що наші тут відносини будуть щирими і дружніми, і будуть засновані на взаємній ввічливості та услузі» [9, л. 1]. Уже 24 мая 90 офицеров и 300 казаков отправились военным эшелоном в Украину.

Вторым фактором, но не менее важным в годы разрухи, являлись экономические отношения. А. М. Квасницкий сообщал, что значительная часть белорусского леса находила свой рынок сбыта на территории Украины, взамен чего Белоруссия получала зерно и сахар. Важность природных богатств Белоруссии для экономики Украины подтверждала и Белорусская торговая палата в Киеве, которая сообщала, что ежедневно 
поступали заявления от общественных учреждений горнопромышленного угольного района, кооперативов, городов и земств, указывавших на свое критическое положение из-за отсутствия топлива и крепежного материала.

В августе 1918 г., в связи с подписанием Добавочного договора между Германией и Россией, планируемое освобождение территорий Беларуси и Украины немецкими войсками поставили в неопределенное положение вопрос о белорусско-украинском сотрудничестве. Украинской стороной ставится под сомнение деятельность Белорусской торговой палаты, вопрос о признании суверенитета Белоруссии откладывается. Белорусская делегация заявляет о прекращении переговоров и уезжает в Минск.

В то же время, завершившиеся ничем в сентябре 1918 г. украинскороссийские переговоры и явное нежелание СНК РСФСР признавать национальные правительства Белоруссии и Украины заставляли искать пути сближения между ними. Продовольственный вопрос оставался актуальным, в связи с чем в Киев была отправлена специальная комиссия для проверки деятельности торговой палаты, во главе с А. Цвикевичем и М. Довнар-Запольским. Комиссия наделялась широкими полномочиями и, проведя реорганизацию работы палаты, предложила в декабре 1918 г. заключить торговое соглашение на равных правах с Украинским государством. Но дни правления Павла Скоропадского уже подходили к своему завершению.

Таким образом, на создание украинского консульского представительства в Минске влияло множество факторов: от беженского вопроса до геополитической угрозы. Деятельность украинских партий и общественных организаций на территории Белоруссии протекала в тесной связи с национальным движением в Украине. Это способствовало более активному объединению украинцев (беженцев и солдат) для защиты своих интересов в различных организация: радах, громадах. В условиях немецкой оккупации наиболее действенной становится работа консульского агентства. Инициатива украинских общественных организаций по открытию консульства в Минске способствовала открытию белорусского консульства в Киеве. Деятельность украинского консульского агентства была разнообразной, но в основном заключалась в решении беженского вопроса и налаживании торгово-экономических отношений между Белоруссией и Украиной.

\section{ИСТОЧНИКИ}

1. Вестник комитета Западного фронта. 1917. № 294 (450).

2. Вестник комитета Западного фронта. 1917. № 378 (534). 
3. Национальный архив Республики Беларусь (НАРБ). Фонд 325. Оп. 1. Д. 6.

4. НАРБ. Фонд 325. Оп. 1. Д. 19.

5. Українська Центральна Рада. Документи і матеріали у двох томах. Київ, 1997. Т. 2.

6. Центральный государственный архив высших органов власти Украины (ЦГАВО). Фонд 3766. Оп. 1. Д. 191.

7. ЦГАВО. Фонд 3766. Оп. 3. Д. 9.

8. НАРБ. Фонд 325. Оп. 1. Д. 8.

9. ЦГАВО. Фонд 3766. Оп. 3. Д. 33.

10. Ц ЦАВО. Фонд 3766. Оп. 1. Д. 68.

PhD Alexander Kuksa (Minsk, Belarus)

DIPLOMATIC RELATIONS OF THE BELARUSIAN PEOPLE'S REPUBLIC AND THE UKRAINIAN STATE (1918)

The article contains a detailed description of the Belarusian-Ukrainian political and diplomatic relations during the Ukrainian State in 1918. Although the Ukrainian State did not recognize the independence of the Belarusian People's Republic, but the Ukrainian consulate functioned in Minsk. The lack of unity of the bourgeois national states in the ruins of the Russian Empire led to the loss of their independence until 1920. Key-words: Belarusian People's Republic of Belarus, Belarus, Ukrainian State, Getman Pavel Skoropadsky.

доцент Александр Кукса (Минск, Беларусь)

ДИПЛОМАТИЧЕСКИЕ ОТНОШЕНИЯ БЕЛОРУССКОЙ
РЕСПУБЛИКИ И ПРАВИТЕЛЬСТВА ПАВЛА СКОРОПАДСКОГО (1918)

Статья содержит подробное описание белорусско-украинских политических и дипломатических отношений в 1918 году. Хотя Украинское Государство не признавало независимости Белорусской Народной Республики, но украинское консульство функционировало в Минске. Отсутствие единства буржуазных национальных государств на руинах Российской империи привело к потере их независимости до 1920 года.

Ключевые слова: Белорусская Народная Республика, Беларусь, Украинская Держава, Гетман Павел Скоропадский.

доцент Олександр Кукса (Мінськ, Білорусь)

ДИПЛОМАТИЧНІ ВІДНОСИНИ БІЛОРУСЬКОЇ НАРОДНОЇ РЕСПУБЛІКИ ТА УРЯДУ ПАВЛА СКОРОПАДСЬКОГО (1918)

Стаття містить докладний опис білорусько-українських політичних і дипломатичних відносин в 1918 році. Хоча Українська Держава не визнавала незалежності Білоруської Народної Республіки, але українське консульство функціонувало в Мінську. Відсутність єдності буржуазних національних держав 
на руїнах Російської імперії призвела до втрати їхньої незалежності протягом 1919-1920 pp.

Ключові слова: Білоруська Народна Республіка, Білорусь, Українська Держава, Гетьман Павло Скоропадський.

* Кукса Александр Николаевич - кандидат исторических наук, доцент кафедры «Политология, социология и социальные учения» Белорусского национального технического университета. E-mail: akuksa@bntu.by. 